\title{
Cytokine Gene Expression, Immune Responses and Disease Resistance of Oncorhynchus mykiss after Raphanus sativus By-products Supplementation
}

\author{
Gökhan Arslan ${ }^{1, *}$ (D) \\ ${ }^{1}$ Atatürk University, Faculty of Fisheries, Department of Seafood Processing Technology, Erzurum, Turkey.
}

\section{How to cite}

Arslan, G. (2021). Cytokine Gene Expression, Immune Responses and Disease Resistance of Oncorhynchus mykiss after Raphanus sativus By-products Supplementation. Turkish Journal of Fisheries and Aquatic Sciences, 21, 521-535. http://doi.org/10.4194/1303-2712-v21_10_05

\section{Article History}

Received 12 January 2021

Accepted 20 June 2021

First Online 24 June 2021

\section{Corresponding Author}

Tel.: +905327431571

E-mail: gokhan.arslan@atauni.edu.tr

\section{Keywords}

Radish seed

Rainbow trout

Cytokine responses

By-product

Growth promoter

\begin{abstract}
In the present study, we examined the effects of aqueous methanolic extract of radish seed (Raphanus sativus) by-products (RS) on innate immune responses and growth performance of rainbow trout (Oncorhynchus mykiss). The fish was fed diets containing 4 different doses of RS (0 \% (Control), $0.1 \%$ (RS0.1), $0.5 \%$ (RS0.5) and $1 \%$ (RS1)) for 14 days. The results showed an increased activity of respiratory burst in fish of treatment groups compared to that of control on 14th day $(P<0.05)$. An enhanced bacterial killing activity was observed in R.05 and RS1 treatment groups compared to control $(P<0.05)$ on 7 th day of the study. Lysozyme activity was elevated in fish of RS1 group on 7th day, and in all treatment groups on 14th day compared to that of the control. Myeloperoxidase activity increased significantly in RS1 and RS0.1 groups compared to the control on 7th day. IL-1b was up- regulated in head kidney of fish in RSO.1 group on $7^{\text {th }}$ day and in RSO 5 group on $14^{\text {th }}$ day of the study. In intestine of fish of experimental groups, IL-1b expression was significantly elevated on $7^{\text {th }}$ day compared to the control. IL-12 was also up-regulated both in kidney and intestine of treatment group fish on $7^{\text {th }}$ day. Similar results were observed on IL-10 expression. IL8 was up-regulated both in kidney and intestine of treated fish groups. Growth performance was affected positively in the RS1 group compared to the control. However, FCR value did not vary among different groups. Survival also improved against Aeromonas hydrophila infection in RS administered fish. All these results suggest that supplementation of RS through diets for 7 days could improve immune responses and growth in rainbow trout.
\end{abstract}

\section{Introduction}

As a rapidly developed industry, aquaculture plays a significant role in the world economy. Thus, aquaculture contributes more than 53 percent to the world fisheries production with its USD 232 billion value (FAO, 2018). In recent years, improved new technologies (Recirculatory aquaculture systems, intensive fish farming units, oxygen supplementation etc.) contribute to this advancement of aquaculture
(Bilen et al., 2015). However, disease outbreaks, climate change risks, and unavailability of feed ingredients also seem new challenges in aquaculture (FAO, 2018).

In the last few decades, fish producers and researchers have focused on improving fish health using different types of immunostimulants (Elbesthi et al., 2020). For this purpose, medicinal herbs are also taken into consideration for their large species diversity and possessing many potential ingredients that have antibacterial, antiviral, and antifungal activities (Dulger 
et al., 2005; Dulger et al., 2009). Also, medicinal plants are used as a reproductive promoter in some cases (Sonmez et al., 2019).

Radish (Raphanus sativus) belongs to the family Brassicaceae and has various medicinal properties. Chevalier (1996) reported laxative effect of radish in digestive system. It was also used traditionally for treatment of pulmonary complications and asthma (Duke and Ayensu, 1985). Radish has also very efficient antibacterial and anti-fungal activities even against fish pathogen, such as Hafnia alvei (Rani et al., 2008).

Rainbow trout is one of the most cultivated fish species in Europe. However, fish farms are often infected by pathogens, such as Aeromonas spp., Flavobacterium spp. (Capkin et al., 2015) and Yersinia ruckeri (Öztürk and Altınok, 2014). Use of medicinal plants as an alternative remedy to improve fish health to fight against pathogens is a new approach (Bilen and Elbeshti, 2019).

Cytokines are important protein mediators in immune system (Ravan and Sakai 2006). Epithelial cells, mast cells, lymphocytes, macrophages and granulocytes are the main sources of the cytokines. Cytokines regulate apoptosis, hematopoiesis, inflammation, antiinflammation, proliferation and cell migration (Sakai et al., 2020).

Aeromonas hydrophila, is a Gram-negative rodshaped bacterium, responsible from motile Aeromonas septicemia (Jun et al., 2013). The bacteria were previously observed in many different fish species and resulted with high loses (Zhu et al., 2020; Jun et al., 2013; Qin et al., 2016; da Silva et al., 2012).

Cold pressed oil production from medicinal plants and their seed is an important industry and these oils are well known for their beneficial health effects. However, after oil production, dregs are used for farm animal feeding or generally wasted. In the present study, using different extraction techniques we obtained several contents from the by-product of radish seed. Then, possible immunostimulant effects of the radish byproduct aqueous methanolic compounds were assessed by examining immune responses in peripheral blood serum, and also in kidney and intestine tissues of rainbow trout. Treated fish was also challenged with the Aeromonas hydrophila at the end of the study.

\section{Material and Methods}

\section{Experimental Fish and Experimental Design}

Rainbow trout (Mean weight: $31.81 \pm 0.04 \mathrm{~g}$ ) juveniles were obtained from a commercial aquaculture farm in Kastamonu. Before the start of the experiment, the fish were acclimatized in a recirculatory tank system maintained at $16^{\circ} \mathrm{C}$ and fed with a commercial diet for two weeks in the Aquarium Unit at Kastamonu University, Faculty of Fisheries. Each treatment was provided with triplicate (40 fish per aquarium, total 12 aquariums, $110 \mathrm{~L}$ each) in recirculation system (8.2-9,3 $\mathrm{mg} / \mathrm{L}$ dissolved oxygen, 8.1-8.4 pH, 0.02-0.05 mg/L ammonium, $0.03-0.05 \mathrm{mg} / \mathrm{L}$ nitrite.). During the study, the water temperature was maintained at $16^{\circ} \mathrm{C}$, and $20 \%$ of the water was exchanged daily. Raphanus sativus aqueous methanolic extract was added to the fish diet at a rate of $0 \%$ (Control), $0.1 \%$ (RSO.1), $0.5 \%$ (RSO.5) and $1 \%$ (RS1). The fish were fed with these diets twice daily for 14 days.

\section{Preparation of Raphanus sativus Extract}

Radish seeds were ground into a fine powder in a mechanical grinder, and $50 \mathrm{~g}$ sample was added to $1 \mathrm{~L}$ of $40 \%$ methanol (Sigma-Aldrich). The mixture was then kept at room temperature for 3 days and stirred every day. After 3 days, Raphanus sativus extract was filtered through a filter paper (Whatman filter No. 1), and the filtrate was collected and evaporated in a rotary evaporator at $55-65^{\circ} \mathrm{C}$ to remove the methanol. The final product was dissolved in distilled water. Extract solution was added to experimental diets at specified concentrations. The methanolic extract of Raphanus sativus was diluted with $50 \mathrm{~mL}$ of distilled water and then, the Raphanus sativus was sprayed on the fish diet at concentrations of 0.1 (RSO.1), 0.5 (RSO.5), and $1 \mathrm{~g}$ kg-1 (RS1) and stored in plastic zip pack at $-20^{\circ} \mathrm{C}$ until use (Bilen et al., 2016).

\section{Sample Collection}

On 7th and 14th day of the study, kidney, intestinal tissues and blood samples were collected from the animals of each experimental group and sampled separately. For this, three fish from each aquarium (total nine fish from each experimental group) were randomly selected, and were anesthetized with phenoxyethanol at $0.01 \mathrm{~mL} / \mathrm{L}$.

\section{Nonspecific Immune Parameters}

\section{Respiratory Burst Activity}

Respiratory burst activity of the phagocytes was carried out according to Siwicki et al. (1994). Briefly, heparinized blood sample $(0.1 \mathrm{~mL})$ was inserted to the bottom of a glass tube to investigate nitroblue tetrazolium (NBT) reduction activity. Then, $0.2 \%$ NBT was added and incubated for another $30 \mathrm{~min}$ at $25^{\circ} \mathrm{C}$. One $\mathrm{mL} \mathrm{N}, \mathrm{N}$-dimethylformamide was added to the mixture to stop activity and it was centrifuged at $3000 \mathrm{x}$ $\mathrm{g}$ for $10 \mathrm{~min}$.

\section{Bacterial Killing Activity}

The bacterial killing activity of blood phagocytic cells was measured according to the methodology modified by Siwicki et al. (1994). Initially, $50 \mu \mathrm{L}$ of blood was added to $50 \mu \mathrm{L}$ culture medium that includes fetal bovine serum and antibiotic mix in a microtiter plate. 
The mixture was incubated at room temperature for $1 \mathrm{~h}$ in order to ensure the cells adhered to the plastic surfaces. Then the supernatant and non-adherent cells were removed using a pipette. Fifty $\mu \mathrm{L}$ NBT in PBS solution containing live $1 \times 10^{8}$ Aeromonas hydrophila cells was added. This suspension was centrifuged at $1500 \times \mathrm{g}$ for $5 \mathrm{~min}$ to bring the bacteria into contact with the adherent cells and incubated at room temperature for 30-60 min. Then, the supernatant was pipetted and $200 \mu \mathrm{L}$ absolute methanol was added to fix cells. After incubation for 2-5 $\mathrm{min}$, the supernatant was thrown out. The cells were rinsed four times with $70 \%$ methanol and then the microplate was dried in fume cupboard for $40 \mathrm{~min}$ to move away methanol. After that, $100 \mu \mathrm{L}$ of $2 \mathrm{M}$ $\mathrm{KOH}$ and $70 \mu \mathrm{L}$ of dimethyl sulfoxide (DMSO) were added to solubilize the formazan. This mixture was incubated for $5 \mathrm{~min}$, and the plates were placed in the microplate reader set for readings at $620 \mathrm{~nm}$; the $\mathrm{KOH}$ DMSO combination was used as the blank.

\section{Lysozyme Activity Test}

Lysozyme activity (LA) was determined according to Ellis (1990) using the turbidimetric assay with minor modifications. In brief, $160 \mathrm{~mL}$ suspension of Micrococcus lysodeikticus (Sigma-Aldrich) was mixed with $40 \mathrm{~mL}$ of fish serum. The rate of lysis was detected against $M$. lysodeikticus. Mixture was measured after 0 and $4 \mathrm{~min}$ at $530 \mathrm{~nm}$ wavelength by a microplate reader (Thermo Multiskan Go).

\section{Myeloperoxidase Activity Test}

Total myeloperoxidase (MPO) content was measured by the method described by Sahoo et al. (2005). In a 96-well plate, $30 \mu \mathrm{L}$ serum was diluted with $370 \mu \mathrm{L}$ of Hank's Balanced Salt solution without $\mathrm{Ca}_{2}+$ or $\mathrm{Mg}_{2}+$ (Sigma Aldrich, Germany). Thousand $\mu \mathrm{L}$ of $0.1 \mathrm{mg}$ $\mathrm{mL}^{-1} 3,3^{\prime}, 5,5^{\prime}$-tetramethylbenzidine dihydrochloride and $0.006 \%$ fresh hydrogen peroxide were added to the diluted serum. The reaction was followed kinetically by measuring the increase in absorbance ratios. Reaction velocities were determined as IU, defined as the amount of enzyme required to produce a 0.001 increase in absorbance per minute for $0.5 \mathrm{~mL}$ of reaction mixture $(\Delta \mathrm{A} 450 / \mathrm{min} / \mathrm{mL})$.

\section{Total Protein and Total IgM Content}

Total protein was measured by Bradford assay using bovine serum albumin (BSA) as the standard. Total IgM was determined according to Anderson and Siwicki (1995). Briefly, $100 \mu \mathrm{l}$ of serum was mixed with an equal volume of $12 \%$ polyethylene glycol (Sigma P3015). After $2 \mathrm{~h}$ incubation, the sample was centrifuged for $10 \mathrm{~min}$ at $5000 \mathrm{rpm}$. Total IgM content was calculated by subtracting the protein content of supernatant from the total protein content in plasma.

\section{Anti-protease Activity}

Serum anti-trypsin activity was measured according to Lange et al. (2001). Twenty $\mu$ of trypsin (Sigma-Aldrich, $5 \mathrm{mg} / \mathrm{ml}$ ) was incubated with same amount of serum for $10 \mathrm{~min}$ at $22^{\circ} \mathrm{C}$. After that, $200 \mu \mathrm{l}$ of $0.1 \mathrm{M} \mathrm{PBS}$ and $250 \mu \mathrm{l}$ of $2 \%$ azocasein solution were mixed. After $1 \mathrm{~h}$ at $22{ }^{\circ} \mathrm{C}, 10 \%$ trichloro acetic acid (TCA) was added to stop the reaction. After $20 \mathrm{~min}$ of incubation, the mixture was centrifuged at $6000 \times \mathrm{g}$ for $5 \mathrm{~min}$. The supernatant was transferred to a 96-well plate containing $100 \mu$ of $1 \mathrm{~N} \mathrm{NaOH}$. The absorbance was read at $410 \mathrm{~nm}$. Positive control (100\%) was prepared by replacing the serum with buffer. For negative control, buffer replaced both serum and trypsin. The percentage inhibition of trypsin activity was calculated by comparing it with a positive control sample.

\section{Serum Alternative Complement (ACH50) Activity}

The hemolytic complement activity was determined according to Ortuno et al. (1998) with a slight modification. Hundred $\mu$ l of serum sample was serially diluted up to $11^{\text {th }}$ well with an equal volume of HBSS in a 96-well plate. Hundred $\mu$ of $3 \%$ SRBC in HBSS was added to all the wells. Then, $100 \mu$ ldistilled water or HBSS was added to SRBC to calculate $100 \%$ and $0 \%$ hemolysis, respectively and the plate was incubated at $22^{\circ} \mathrm{C}$ for $1 \mathrm{~h}$. After that, samples were centrifuged at $1500 \mathrm{rpm}$ for $4^{\circ} \mathrm{C}$. One hundred fifty $\mu \mathrm{l}$ of supernatant was transferred to a fresh plate and the hemoglobin content of the supernatant was assessed by measuring its OD at $540 \mathrm{~nm}$. The lysis curve was generated by plotting percent hemolysis against the volume of test serum added $(\mathrm{ml})$. The volume yielding $50 \%$ hemolysis (ACH50 units/ $\mathrm{ml}$ ) was determined for each group.

\section{Analysis of Cytokine Gene Expression}

\section{RNA Extraction}

Approximately $30 \mathrm{mg}$ of kidney and intestine samples were taken from each fish and stored in RNAlater solution for RNA extraction. From the total RNA extracted, cDNA synthesis was achieved via reverse transcription using a BIOLINE kit (ISOLATE II RNA Mini Kit) according to the manufacturer's protocol. The quantity and quality of all RNA samples were checked using a Multiscan GO spectrophotometer (ThermoFischer Scientific, USA).

\section{cDNA Synthesis}

The extracted RNAs were subjected to treatment with $1 \mathrm{U}$ DNase I (BIOLINE) in order to completely remove genomic DNA. The extracted total RNA was used for cDNA synthesis via reverse transcription from $1 \mu \mathrm{g}$ mRNA using a BIOLINE kit (SensiFAST ${ }^{\mathrm{T}}$ CDNA Synthesis 
Kit). The cDNA reaction mixture contained $1 \mu \mathrm{g}$ of template RNA, $15 \mathrm{pmol} / \mu \mathrm{L}$ oligo dT primer, $4 \mu \mathrm{L} 5 \times$ TransAmp Buffer, $1 \mu \mathrm{L}$ of Reverse Transcriptase, oligo dT primer and was made up to $20 \mu \mathrm{L}$ with nuclease free water (NFW). The reaction mixture was incubated for 10 min at $25^{\circ} \mathrm{C}$ for primer annealing, $15 \mathrm{~min}$ at $42^{\circ} \mathrm{C}$ for reverse transcription and $5 \mathrm{~min}$ at $85^{\circ} \mathrm{C}$ for inactivation of reaction in a thermal cycler (ThermoFischer Scientific).

\section{Quantitative Real Time Polymerase Chain Reaction (qRT-PCR) Analyses of Gene Expression}

After cDNA synthesis, qRT-PCR was performed using CFX Real-Time PCR Detection Systems (Bio-Rad, $A B D$ ) and SensiFAST SYBR No-ROX PCR Kit (BIOLINE, $A B D)$. Gene specific primer sequences and references are enlisted in Table 1. qRT-PCR mixture included 12.5 $\mu \mathrm{L}$ of $2 \times$ SYBR Green Master Mix, $0.1 \mu \mathrm{g}$ of template DNA, $0.4 \mu \mathrm{M}$ of each gene specific forward and reverse primer (IL-1 $\beta$, IL-6, IL-8, IL-10 and IL-12) and NFW to the final volume of $20 \mu \mathrm{L}$. qRT-PCR steps involved were: denaturation at $95^{\circ} \mathrm{C}$ for $20 \mathrm{~s}$, annealing at $60^{\circ} \mathrm{C}$ for $1 \mathrm{~min}$ and extension step at $72^{\circ} \mathrm{C}$ for $30 \mathrm{~s}$. Fluorescence signals were picked up at $530 \mathrm{~nm}$ wavelength from $60^{\circ} \mathrm{C}$ to $95^{\circ} \mathrm{C}$ at every $0.5^{\circ} \mathrm{C}$ per second to implement melting curve analysis. qRT-PCR was achieved with 3 different samples from experimental and control groups, and 3 technical replicates were evaluated for each sample. The $\Delta C T$ and $\triangle \Delta C T$ were estimated by $\Delta C T=C T$ target geneCTreference and $\Delta \Delta C T=\Delta C T$ treated sample $-\Delta C T$ control sample. The results were measured using $2^{-\Delta \Delta C T}$ method to calculate relative gene expression. The standard error of means between replicates was computed simultaneously.
Gas Chromatography-mass Spectrometry (GC-MS) Analysis of Radish Seed By-Product (Raphanus sativus)

The GC-MS analysis of the samples extorted after aqueous methanolic extracts was determined using a Shimadzu Mass Spectrometer- QP 2010 Ultra equipped with Rtx-5MS capillary column (30 m.0.25 mm; coating thickness $0.25 \mu \mathrm{m}$ ). The compounds were identified by comparing with the standards, or the mass spectra were matched with the Wiley Data Library (Table 2).

\section{Challenge Test}

At the end of feeding trial, fish were challenged with Aeromonas hydrophila (SBAh1) (Bilen et al., 2019b). The strain was previously isolated from diseased fish and identified by biochemical and PCR methods. Challenge test was performed as described in our previous study (Bilen et al., 2016). Briefly, A. hydrophila with $1 \times 10^{7}$ CFUs mL ${ }^{-1}$ mixed in $100 \mathrm{~mL}^{\text {PBS }}$ was injected to all fish intra-peritoneally at the end of the dietary feeding trial (after 14 days). Dead O. mykiss was removed from the tank and mortality was recorded daily for 10 days. A. hydrophila was re-isolated from the dead fish to confirm the mortality caused by the bacterial infection. After 10 days post injection, survival rate of groups was calculated using this formulae: SR (\%)= (number of fish survived/number of fish injected) $\times 100$.

\section{Statistical Analysis}

One-way analysis of variance (ANOVA) and Duncan's Multiple Range Test were used to determine any difference in non-specific immune parameters, cytokine gene expressions and survival rate at $\mathrm{P}<0.05$.

Table 1. Primers used in qRT-PCR for analysis of immune gene expressions in the study.

\begin{tabular}{|c|c|c|}
\hline Gene & Primer Sequence & Reference \\
\hline \multirow{2}{*}{ B-actin } & F5'ATGGAAGGTGAAATCGCC 3' & \multirow{2}{*}{ Sigh at al. 2004} \\
\hline & & \\
\hline \multirow{2}{*}{ IL-1 $\beta$} & F5'ACCGAGTTCAAGGACAAGGA 3' & \multirow{2}{*}{ Awad at al. 2011} \\
\hline & R5' CATTCATCAGGACCCAGCAC 3' & \\
\hline \multirow{2}{*}{ IL-8 } & F5'CACAGACAGAGAAGGAAGGAAAG 3' & \multirow{2}{*}{ Awad at al. 2011} \\
\hline & R5'TGCTCATCTTGGGGTTACAGA 3' & \\
\hline \multirow{2}{*}{ IL- 6} & F5'CAAGGATGCTTGTCTACGAAGG 3' & \multirow{2}{*}{ Awad at al. 2011} \\
\hline & R5'GCTCTTTGATCAGGATGTTGCT 3' & \\
\hline \multirow{2}{*}{ IL-10 } & F5' CGACTTTAAATCTCCCATCGAC 3' & \multirow[b]{2}{*}{ Raida and Buchmann 2008} \\
\hline & R5'GCATTGGACGATCTCTTTCTTC 3' & \\
\hline \multirow{2}{*}{ IL-12 } & F5' GAACCCAGACGACGATGATT 3' & \multirow{2}{*}{ Komatsu et. al. 2009} \\
\hline & R5' GTTCAAACTCCAACCCTCCA 3' & \\
\hline \multirow{2}{*}{ IFN-1 } & F5'CAAGAAGTGGGCATGTGATCTGT 3' & \multirow[b]{2}{*}{ Ooi at al 2008} \\
\hline & R5' AGAATGCCCCAGTCCTTTTTCC $3^{\prime}$ & \\
\hline \multirow{2}{*}{ IFN-2 } & F5'GTTGAGGGCCATGGATGTG 3' & \multirow{2}{*}{ Ooi at al 2008} \\
\hline & R5' TCCAGCCCATCAAGCAGAA3' & \\
\hline \multirow{2}{*}{ TGF- $\beta$} & F5' AGATAAATCGGAGAGTTGCTGTG 3' & \multirow{2}{*}{ Awad at al 2011} \\
\hline & R5'CCTGCTCCACCTTGTGTTGT 3' & \\
\hline \multirow{2}{*}{ TNF- $\alpha$} & F5' CAAGAGTTTGAACCTTGTTCAA $3^{\prime}$ & \multirow{2}{*}{ Panigrahi at al 2007} \\
\hline & R5' GCTGCTGCCGCACATAGAC 3' & \\
\hline
\end{tabular}


Homogeneity of variances was determined using Kolmogorov-Smirnov test and Levene's test.

\section{Results}

In the present study, at the end of 14-day trial adaptive immune responses were presented in Table 3.

The results showed no differences in NBT reduction at $7^{\text {th }}$ day of the $(P>0.05)$. However, on $14^{\text {th }}$ day of the study, in all treatment groups, respiratory burst was significantly increased compared to that of control. Bacterial killing activity was elevated in RSO.5 and RS1 groups compared to RS0.1 and control at $7^{\text {th }}$ day of the study. The highest activity was observed in RS1 on $14^{\text {th }}$ day compared to other treatments $(P<0.05)$. LA was enhanced in RS0.5 and RS1 $(P<0.05)$ and no differences were observed between RSO.1 and control $(P>0.05)$ on $7^{\text {th }}$ day of the study. In all treatment groups, LA was significantly increased at $14^{\text {th }}$ day of the study. MPO was elevated in RS0.5 and RS1 groups compared to RSO.1 and control $(P<0.05)$ at $7^{\text {th }}$ day of the study. At the end of the study, interestingly MPO activity in all treatments as well as in control was not changed. Total protein was significantly increased in RSO.1 group compare to other on $7^{\text {th }}$ day and in all experimental groups compare to control on $14^{\text {th }}$ day of the study. IgM levels were significantly increased on both the sampling times in all treatment groups compared to that of control. ACH50 was also significantly increased in all treated fish groups compared to control and the highest level was observed in RS1 fish group $(P<0.05)$. An elevated anti-protease activity in treatment groups RS0.1 and RS1 was determined at both sampling times compared to control $(P<0.05)$. No significant difference was observed between control and RSO.5 group.

The results of innate immune gene expressions were summarized in Figures. 1, 2, 3, 4, 5, 6, 7, 8, and 9.

IL-1 $\beta$ expression was up-regulated in kidney and intestine in all experimental groups on $7^{\text {th }}$ and $14^{\text {th }}$ day of the study $(\mathrm{P}<0.05)$.

IL-12 expression result was provided in Figure 2.

Table 2. Composition of aqueous methanolic extract of radish seed (Raphanus sativus) by-products determined using GC-MS

\begin{tabular}{|c|c|c|}
\hline Peak\# & Area\% & Name \\
\hline 1 & 0.39 & Ethanedioic Acid \\
\hline 2 & 2.38 & Acetic acid (CAS) \\
\hline 3 & 0.96 & 2-Propanone, 1-hydroxy- \\
\hline 4 & 0.16 & 1-Penten-3-one (CAS) \\
\hline 5 & 0.25 & 2-Propenoic acid, methyl ester (CAS) \\
\hline 6 & 0.56 & Propanoic acid, 2-oxo-, methyl ester (CAS) \\
\hline 7 & 2.73 & 1,1-Diethoxypropanal \\
\hline 8 & 0.12 & Ethyl orthoformate \\
\hline 9 & 0.38 & Formamide, N-methoxy- \\
\hline 10 & 0.74 & Formamide, $\mathrm{N}$-methoxy- \\
\hline 11 & 1.00 & Formamide, N-methoxy- \\
\hline 12 & 0.22 & 2-Furanmethanol (CAS) \\
\hline 13 & 0.39 & 1,2-Cyclopentanedione \\
\hline 14 & 0.35 & Dimethyl trisulfide \\
\hline 15 & 0.58 & 2(5H)-Thiophenone, 5-methyl- \\
\hline 16 & 0.16 & Benzyl alcohol \\
\hline 17 & 0.65 & Cyclopentane, (methylthio)- \\
\hline 18 & 0.22 & Epithiovaleronitrile \\
\hline 19 & 0.31 & 1,2,3-Propanetriol (CAS) \\
\hline 20 & 0.14 & Benzaldehyde, 3,4-dimethyl- \\
\hline 21 & 0.29 & 4-Methoxymethylphenol \\
\hline 22 & 0.25 & Guaiacol <4-vinyl-> \\
\hline 23 & 0.27 & Vanillin \\
\hline 24 & 0.79 & 3',5'-Dimethoxyacetophenone \\
\hline 25 & 0.14 & Diethyl Phthalate \\
\hline 26 & 13.32 & Benzaldehyde, 4-hydroxy-3,5-dimethoxy- \\
\hline 27 & 13.48 & .alpha.-D-Glucopyranoside, methyl \\
\hline 28 & 3.41 & N-F ormyl-dl-valine \\
\hline 29 & 11.85 & Tetradecanoic acid \\
\hline 30 & 30.97 & 3H-1,2,4-Triazole-3-thione, 1,2-dihydro-4-methyl- (CAS) \\
\hline 31 & 0.12 & 5-ISOPROPYLTETRAHYDROTHIOPHEN-3-ONE \\
\hline 32 & 0.37 & Palmitic acid \\
\hline 33 & 1.83 & n-Hexadecanoic acid \\
\hline 34 & 8.62 & Oleic Acid \\
\hline 35 & $\begin{array}{c}1.59 \\
100.00\end{array}$ & Octadecanoic acid \\
\hline
\end{tabular}


The result demonstrated that IL-12 gene was upregulated almost 30 folds in kidney of fish in all treatment groups compared to control on $7^{\text {th }}$ day of the study $(P<0.05)$. Similar to that, an increased level of expression was also observed in intestine (almost 30 folds) on $14^{\text {th }}$ day of the study.

Similar to kidney results, in intestine, an increased IL-12 expression was observed in fish of all treatment groups $(P>0.05)$ on both sampling time. IL-10 gene expression pattern was similar to that of IL-12 (Figure 3).

Results of IL-6 gene expression were depicted in Figure 4. Results were showed significant increase on both experimental time and both in the kidney and the intestine. IL-8 gene expression level increased in kidney and intestine of fish of treatment groups $(P<0.05)$ on $7^{\text {th }}$ and $14^{\text {th }}$ day. In intestine, IL- 8 gene expression was upregulated on both 7 th and 14 th day of the study in all experimental groups.

Results of IFN-1 and IFN-2 gene expressions were summarized in Figure 6. and 7.

Expression of both of the genes was significantly increased on $7^{\text {th }}$ and $14^{\text {th }}$ day of the study in all treated fish groups compared to control. The highest level of IFN-1 gene expression was observed both in kidney and the intestine on $7^{\text {th }}$ day of the study in RS1 fish group $(\mathrm{P}<0.05)$.

Results of TGF- $\beta$ gene expression were provided in Figure 8. In kidney, there was no significant difference in fish of the treatment groups compared to that of the control. However, in intestine, TGF- $\beta$ gene expression was significantly elevated in fish of all treated groups compared to the control on $7^{\text {th }}$ and $14^{\text {th }}$ day of the study.

In Figure 9, TNF- $\alpha$ gene expression was presented. Similar to IL-10 results, an increased level of expression was observed in head kidney and intestine at both sampling times $(\mathrm{P}<0.05)$ in all experimental groups compared to that of control.

Growth performance results were presented in Table 4.

At the end of the study, final weight of fish in RS1 group was significantly higher. Similar to this, the highest SGR was also determined in RS1 treatment. In all treatment groups, FCR values were decreased but were not significantly lower compared to that of control ( $P>0.05)$.

Survival of rainbow trout after challenged with $A$. hydrophila was presented in Figure 10 . The result demonstrated that survival rate was significantly higher in all experimental groups compared to control $(P<0.05)$. Interestingly, the highest survival rate was observed in RS0.1 treatment group $(P<0.05)$.

\section{Discussion}

Over the last few decades, potential effects of medicinal herbs on immune responses, protection to pathogens and growth promotion have been demonstrated in fish (Bilen et al., 2016; Bilen and Elbeshti, 2019; Bilen et al., 2019d). Besides, antimicrobial resistance especially against fish pathogens forced aquaculturists to find alternative and natural sources. In the present study, positive effects of radish have been observed on fish immune system and growth promotion, even though it was used for a short span. Protection against one of the most important fish pathogens, $A$. hydrophila was also significantly elevated.

Respiratory burst activity increased during last sampling time in the radish extract treated fish groups but it was not significantly higher. Similarly, in earlier studies, an enhanced respiratory burst activity was observed after Melissa officinalis (Bilen et al., 2019a)

Table 3. Non-specific immune responses of rainbow trout fed with different doses of radish seed (Raphanus sativus) by-products aqueous methanolic extract.

\begin{tabular}{|c|c|c|c|c|c|}
\hline & & Control & RS0.1 & RS0.5 & RS1 \\
\hline Respiratory & $7^{\text {th }}$ Day & $0.68 \pm 0.01$ & $0.76 \pm 0.02$ & $0.82 \pm 0.01$ & $0.87 \pm 0.19$ \\
\hline $\begin{array}{l}\text { Burst } \\
(\mathrm{mg} / \mathrm{ml})\end{array}$ & $14^{\text {th }}$ Day & $0.70 \pm 0.03^{b}$ & $1.19 \pm 0.24^{a}$ & $1.09 \pm 0.06^{a}$ & $1.19 \pm 0.04^{a}$ \\
\hline \multirow[t]{2}{*}{ Bacterial Killing Activity } & $7^{\text {th }}$ Day & $0.66 \pm 0.01^{b}$ & $0.63 \pm 0.03^{b}$ & $1.25 \pm 0.01^{\mathrm{a}}$ & $1.57 \pm 0.05^{a}$ \\
\hline & $14^{\text {th }}$ Day & $1.08 \pm 0.06^{a b}$ & $1.07 \pm 0.06^{\mathrm{ab}}$ & $0.91 \pm 0.04^{b}$ & $1.37 \pm 0.15^{a}$ \\
\hline \multirow[t]{2}{*}{ Lysozyme Activity (U/ml) } & $7^{\text {th }}$ Day & $1.14 \pm 0.11^{\mathrm{c}}$ & $1.06 \pm 0.04^{c}$ & $2.40 \pm 0.63^{a b}$ & $3.75 \pm 0.76^{a}$ \\
\hline & $14^{\text {th }}$ Day & $0.66 \pm 0.13^{b}$ & $2.10 \pm 0.09^{a}$ & $2.01 \pm 0.29 a$ & $2.40 \pm 0.29^{a}$ \\
\hline \multirow{2}{*}{$\begin{array}{l}\text { Myeloperoxidase Activity } \\
(540 \mathrm{~nm})\end{array}$} & $7^{\text {th }}$ Day & $40.37 \pm 7.06^{c}$ & $80.78 \pm 15.11^{c}$ & $310.31 \pm 58.86^{b}$ & $831.77 \pm 69.32^{a}$ \\
\hline & $14^{\text {th }}$ Day & $194.98 \pm 10.51$ & $297.16 \pm 52.83$ & $274.85 \pm 70.50$ & $333.33 \pm 23.37$ \\
\hline \multirow[t]{2}{*}{ Total Protein (g/dl) } & $7^{\text {th }}$ Day & $5.71 \pm 0.85^{b}$ & $6.05 \pm 0.41^{a}$ & $5.81 \pm 0.14^{b}$ & $5.83 \pm 0.35^{b}$ \\
\hline & $14^{\text {th }}$ Day & $5.75 \pm 1.02^{b}$ & $5.98 \pm 0.21^{a}$ & $5.83 \pm 0.51^{a}$ & $5.91 \pm 0.27^{a}$ \\
\hline \multirow[t]{2}{*}{ Total IgM (g/dl) } & $7^{\text {th }}$ Day & $2.08 \pm 0.02^{b}$ & $2.75 \pm 0.1^{\mathrm{a}}$ & $2.85 \pm 0.024^{a}$ & $2.97 \pm 0.09 a$ \\
\hline & $14^{\text {th }}$ Day & $2.01 \pm 0.012^{b}$ & $2.70 \pm 0.012^{a}$ & $2.81 \pm 0.014^{a}$ & $2.86 \pm 0.024^{a}$ \\
\hline \multirow[t]{2}{*}{ ACH50 Activity (U/ml) } & $7^{\text {th }}$ Day & $110 \pm 1.26^{c}$ & $126 \pm 2.65^{b}$ & $124 \pm 2.14^{b}$ & $141 \pm 1.47^{\mathrm{a}}$ \\
\hline & $14^{\text {th }}$ Day & $115 \pm 2.36^{c}$ & $125 \pm 3.84^{b}$ & $121 \pm 1.95^{b}$ & $138 \pm 2.05^{a}$ \\
\hline \multirow[t]{2}{*}{ Antiprotease Activity (\%) } & $7^{\text {th }}$ Day & $72.35 \pm 2.65^{b c}$ & $81.25 \pm 1.92^{a}$ & $76.35 \pm 2.01^{b}$ & $79.35 \pm 1.47^{a}$ \\
\hline & $14^{\text {th }}$ Day & $74.25 \pm 3.02^{b}$ & $82.45 \pm 3.54^{a}$ & $76.38 \pm 1.74^{b}$ & $81.25 \pm 1.45^{a}$ \\
\hline
\end{tabular}

RS0.1, RS0.5 and RS1, radish seed (Raphanus sativus) by-products aqueous methanolic extract at $0.1,0.5$ and $1 \%$ diet, respectively. Values are expressed as mean \pm SE. Different superscript letters on values indicate significant differences between groups in a row $(P<0.05)$. 
and Centella asiatica (Srichaiyo et al., 2020) administration. This study exhibited an increase in bacterial killing activity in RS1 group. Similar to our study, seabass and seabream had higher protection against bacteria after common mallow and tetra extract administration (Bilen et al., 2019c).

Myeloperoxidase is also an important enzyme released from neutrophils (Siwicki et al 1994). In the present study, increasing MPO activity was observed in fish of RS1 and RS0.1 groups. Similarly, an increased MPO activity was noticed in rainbow trout fed with Malva sylvestris (Bilen et al., 2020), goldfish fed with Urtica dioica (Bilen et al., 2014) and Nile tilapia fed with Camellia sinensis (Van Doan et al., 2019). However, no effect on MPO activity was observed in carp fed with different doses of Tilia tomentosa (Almabrok et al., 2018).

Lysozyme is a lytic enzyme (Magnadóttir, 2006) that prevents colonization of the bacterial pathogens by lysing bacterial cell walls (Alexander and Ingram, 1992). Lysozyme activity was increased in RSO.1 and RS1 fish groups during both the sampling times. Different components of the RS could be responsible for increasing lysozyme activity. Similarity to our result, Apium graveolens fed carp displayed increasing lysozyme activity (Mohamed et al., 2018). In zebrafish, an elevated lysozyme activity was obtained after administration of apple cider vinegar (Ahmadifar et al., 2019). On the contrary, no effect was observed on carp lysozyme activity after dietary administration of Chenopodium album (Amhamed et al., 2018).

Total protein and Total IgM were significantly increased in the present study in RS fish groups. Elevated total protein and IgM results directly indicate an enhanced immune response in rainbow trout. Similar to that, elevated total protein was determined on rainbow trout fed with Aloe vera (Mehrabi et al., 2019). $\mathrm{ACH} 50$ is an important innate immune component and many different proteins assigned on immune responses in complement system (Pearce et al., 2003). In the present study, an increased $\mathrm{ACH} 50$ activity was determined in all treated fish groups as it has been observed on total protein and IgM levels. Similarly, an elevated activity was also observed in rainbow trout fed with barberry root (Ramezanzadeh et al., 2020). Antiprotease also increased in RS0.1 and RS1 fish groups. Probably, the increased anti-protease activity also regulated the immune response against $A$. hydrophila infection. In line with our study, an elevated antiprotease activity was also reported by several authors (Awad et al., 2013; Awad et al., 2020; Maldonado-Garcia et al., 2019).

IL-1 $\beta$ is one of the key pro-inflammatory cytokines (Zou and Secombes 2016). It activates immune cells against pathogens in fish The present study demonstrated its up-regulation in both kidney and intestine of treated fish at different sampling times. An increased IL-1 $\beta$ gene expression in rainbow trout leucocytes was detected after exposure to cyclopamine (Sönmez et al., 2018). IL-1 $\beta$ gene expression was also elevated in Cyprinus carpio fed with raffinose (Karimi et al., 2020) and ferula (Safari et al., 2016), and in rainbow trout treated with Usnea barbata (Bilen et al., 2019d) and tetra (Bilen and Elbeshti, 2019).

IL-12 is a heterodimeric cytokine that regulates IFN- $\gamma$ production in natural killer cells, B and T cells (Wang et al., 2014). Also, IL-12 activates Th1 and Th2 based immune response (Wangkahart et al., 2019). An elevated transcription of this gene was observed in intestine and kidney of fish in RS treatments. This result may suggest that neutrophils and $T$ cells were stimulated after RS treatment. The enhanced IL-12 transcription could cause high survival in RS treated rainbow trout against $A$. hydrophila infection. Similarly, Juniperus extract has caused IL-12 gene up-regulation in rainbow trout (Bilen et al.).

IL-8 chemokine is also involved in an early inflammatory reaction since it has a chemo-attractive effect on neutrophils in trout (Zhang et al., 2002). During infection, it is released by different immune cells (Tran et al., 2019). It was clearly demonstrated that IL-8 initiates inflammatory reaction in fish against bacterial infection (Wiens et al., 2006). In the present study, IL-8 gene expression was up-regulated in intestine a kidney during both sampling times in RS fish groups. Likewise, Bilen et al. (2019d) detected an increase on IL-8 transcription in rainbow trout treated with Usnea barbata. Contrary to our study, Altunoglu et al. (2017) demonstrated a down-regulation in IL-8 gene expression in rainbow trout administered with black cumin aqueous methanolic extract.

IL-10 is an anti-inflammatory cytokine that may cause down-regulation of inflammation (Raida and Buchmann, 2008; Tran et al., 2019). At the all sampling

Table 4. Growth performance of rainbow trout fed with different doses of radish seed (Raphanus sativus) by-products aqueous methanolic extract.

\begin{tabular}{lccccc}
\hline & Initial Weight $(\mathrm{g})$ & Final Weight $(\mathrm{g})$ & WG $(\%)$ & SGR & FCR \\
\hline Control & $31.88 \pm 0.08$ & $42 \pm 0.19^{\mathrm{b}}$ & $31.74 \pm 0.65^{\mathrm{b}}$ & $1.97 \pm 0.04^{\mathrm{b}}$ & $1.16 \pm 0.05$ \\
RS0.1 & $31.78 \pm 0.04$ & $42.7 \pm 0.69^{\mathrm{ab}}$ & $34.35 \pm 1.00^{\mathrm{ab}}$ & $2.11 \pm 0.05^{\mathrm{ab}}$ & $1.05 \pm 0.01$ \\
RS0.5 & $31.80 \pm 0.04$ & $43.61 \pm 1.32^{\mathrm{ab}}$ & $37.15 \pm 2.40^{\mathrm{ab}}$ & $2.25 \pm 0.12^{\mathrm{ab}}$ & $1.12 \pm 0.03$ \\
RS1 & $31.78 \pm 0.03$ & $44.73 \pm 0.24^{\mathrm{a}}$ & $40.66 \pm 1.38^{\mathrm{a}}$ & $2.44 \pm 0.07^{\mathrm{a}}$ & $1.09 \pm 0.01$ \\
\hline
\end{tabular}

RS0.1, RS0.5 and RS1, radish seed (Raphanus sativus) by-products aqueous methanolic extract at $0.1,0.5$ and $1 \%$ diet, respectively. Values are expressed as mean $\pm \mathrm{SE}$. Different superscript letters on values indicate significant differences between groups in a column $(\mathrm{P}<0.05)$. 
time, IL-10 gene expression was up-regulated in RS fish groups both of the intestine and kidney. Depending on the IL-1 $\beta$ up-regulation, up-regulated IL-10 could normalize anti-inflammatory immune response. Similar to this result, Gharaei et al. (2020) reported an increase in IL-10 gene expression in rainbow trout fed with sumac. IL- 6 is a pro-inflammatory cytokine that activates inflammatory cells and induces acute phase protein synthesis (Dong, 2008). IL-6 gene expression increased clearly in kidney and intestine of RS fish groups. The increased IL- 6 transcription caused a pro-inflammatory response. Increased IL- 6 gene expression was also observed in rainbow trout fed with Aloe vera extract (Mehrabi et al., 2019).
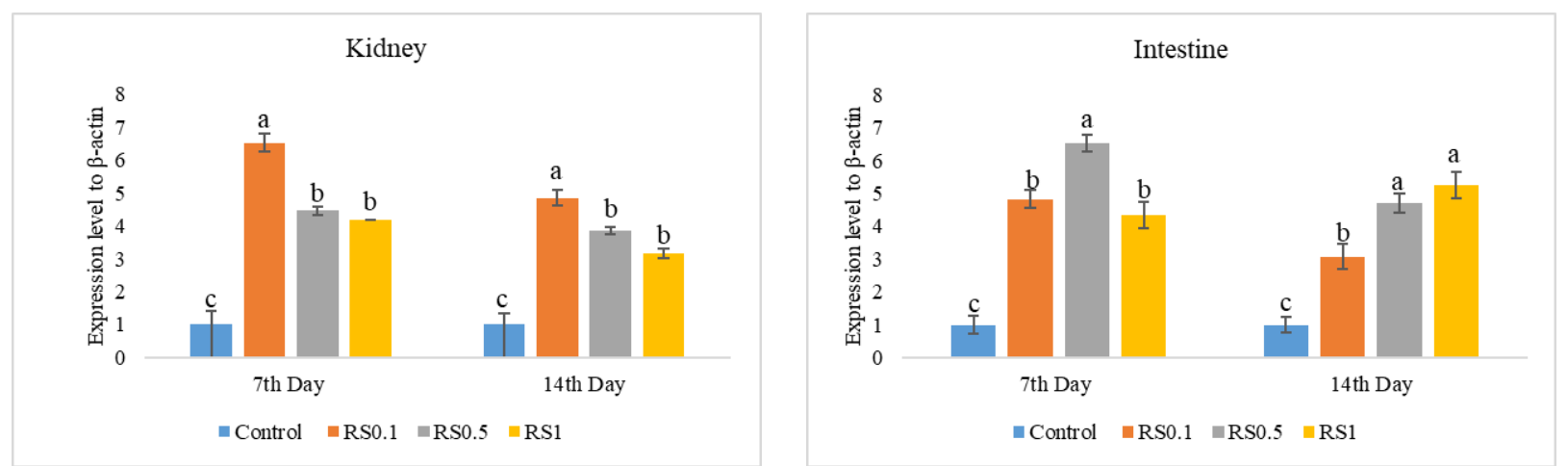

Figure 1. Relative gene expression of IL-1 $\beta$ in the head kidney and intestine cells of rainbow trout treated with different doses of radish seed (Raphanus sativus) by-products aqueous methanolic extract. RS0.1, RSO.5 and RS1, radish seed (Raphanus sativus) byproducts aqueous methanolic extract at 0.10 .5 and $1 \%$ diet, respectively. Values are expressed as mean \pm SE. Different letters above bars indicate significant differences between groups at each sampling day $(\mathrm{P}<0.05)$.
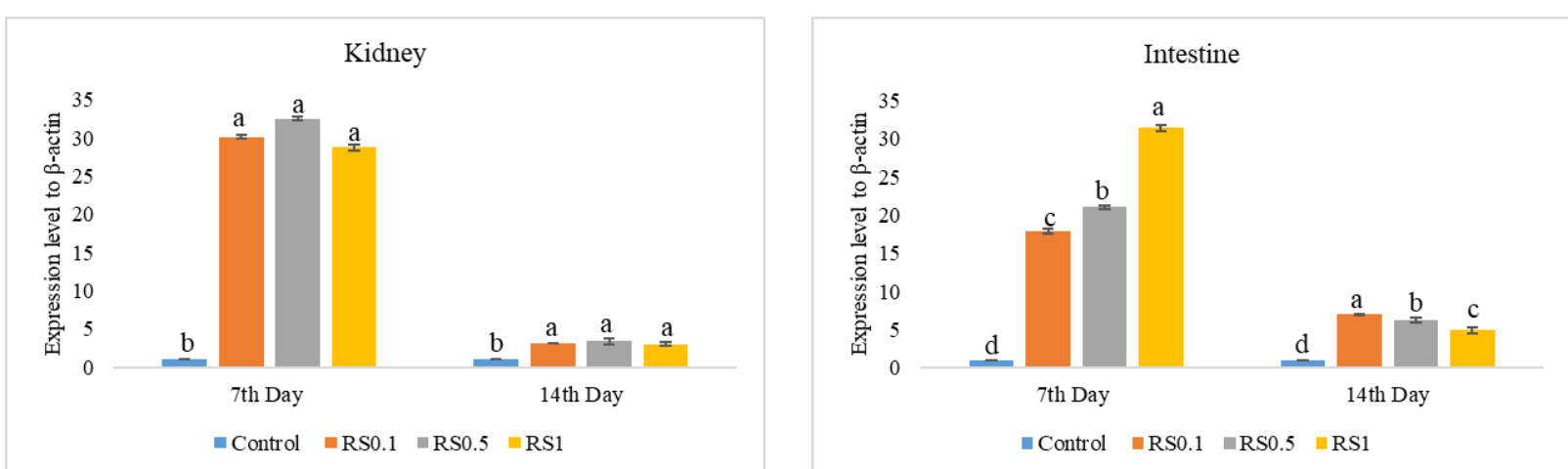

Figure 2. Relative gene expression of IL-12 in the head kidney and intestine cells of rainbow trout treated with different doses of radish seed (Raphanus sativus) by-products aqueous methanolic extract. RSO.1, RSO.5 and RS1, radish seed (Raphanus sativus) byproducts aqueous methanolic extract at 0.10 .5 and $1 \%$ diet, respectively. Values are expressed as mean \pm SE. Different letters above bars indicate significant differences between groups at each sampling day $(P<0.05)$.
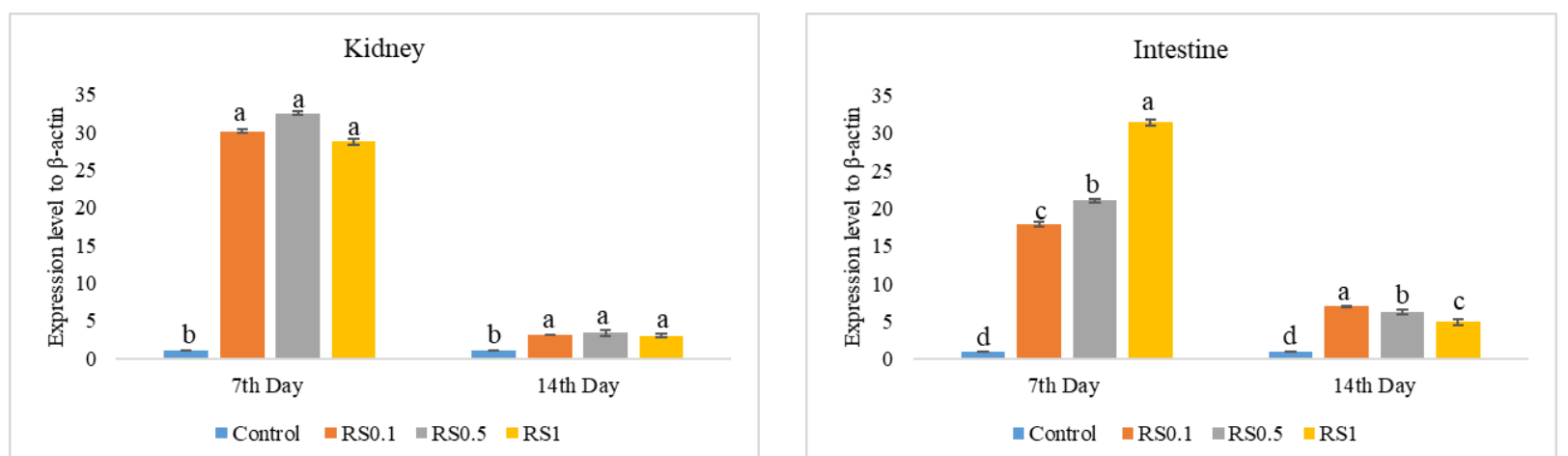

Figure 3. Relative gene expression of IL-10 in the head kidney and intestine cells of rainbow trout treated with different doses of radish seed (Raphanus sativus) by-products aqueous methanolic extract. RS0.1, RS0.5 and RS1, radish seed (Raphanus sativus) byproducts aqueous methanolic extract at 0.10 .5 and $1 \%$ diet, respectively. Values are expressed as mean \pm SE. Different letters above bars indicate significant differences between groups at each sampling day $(P<0.05)$. 
Interferons are generally responsible for defending viruses (Ooi et al., 2008). Both IFN-1 and IFN-2 genes were up-regulated in kidney and intestine of the treated fish. Kucukgul and Gulsafak (2019) also observed an upregulation of IFN gene in kidney of rainbow trout after carvacrol supplementation. TGF- $\beta$ was identified from several fish species, and it possesses an immunosuppressive activity (Zou and Secombes, 2016).
TGF- $\beta$ could prevent the nitric oxide response of TNF- $\alpha$ activated macrophages, and also inhibited the LPS induced elevation of TNF- $\alpha, \quad$ IL- $1 \beta$ and IL- 8 in monocytes/macrophages (Haddad et al., 2008). TGF- $\beta$ gene expression did not show any difference in kidney at both sampling times. However, in intestine, an elevated expression level was observed (up to 14 folds). It is clear from the result that TGF regulation is stronger
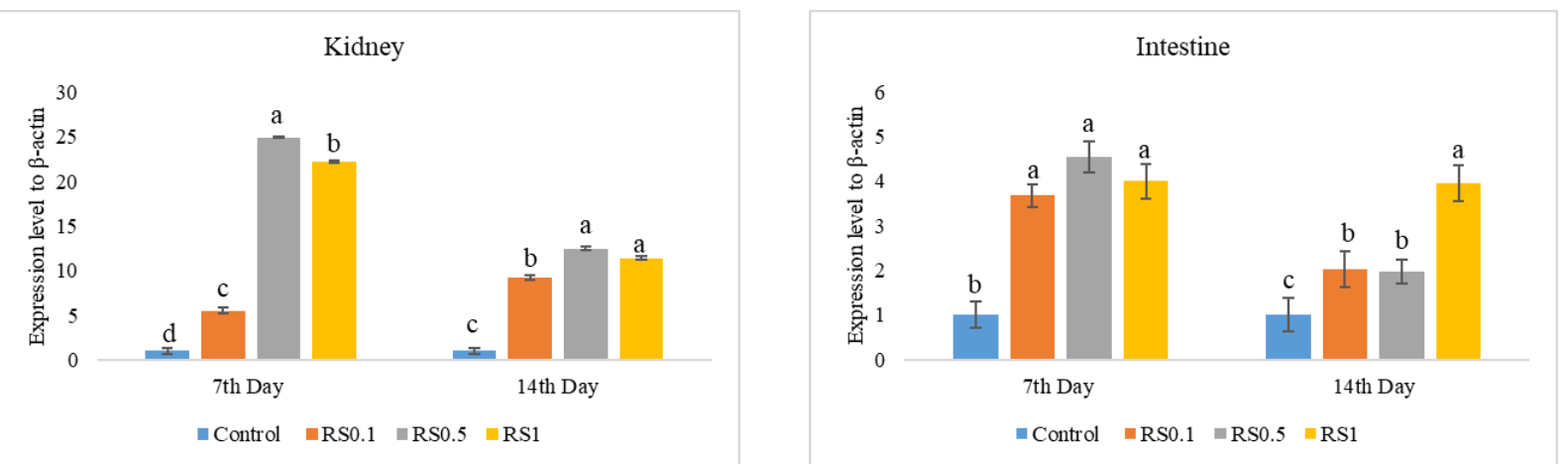

Figure 4. Relative gene expression of IL-6 in the head kidney and intestine cells of rainbow trout treated with different doses of radish seed (Raphanus sativus) by-products aqueous methanolic extract. RS0.1, RS0.5 and RS1, radish seed (Raphanus sativus) byproducts aqueous methanolic extract at 0.10 .5 and $1 \%$ diet, respectively. Values are expressed as mean \pm SE. Different letters above bars indicate significant differences between groups at each sampling day $(\mathrm{P}<0.05)$.
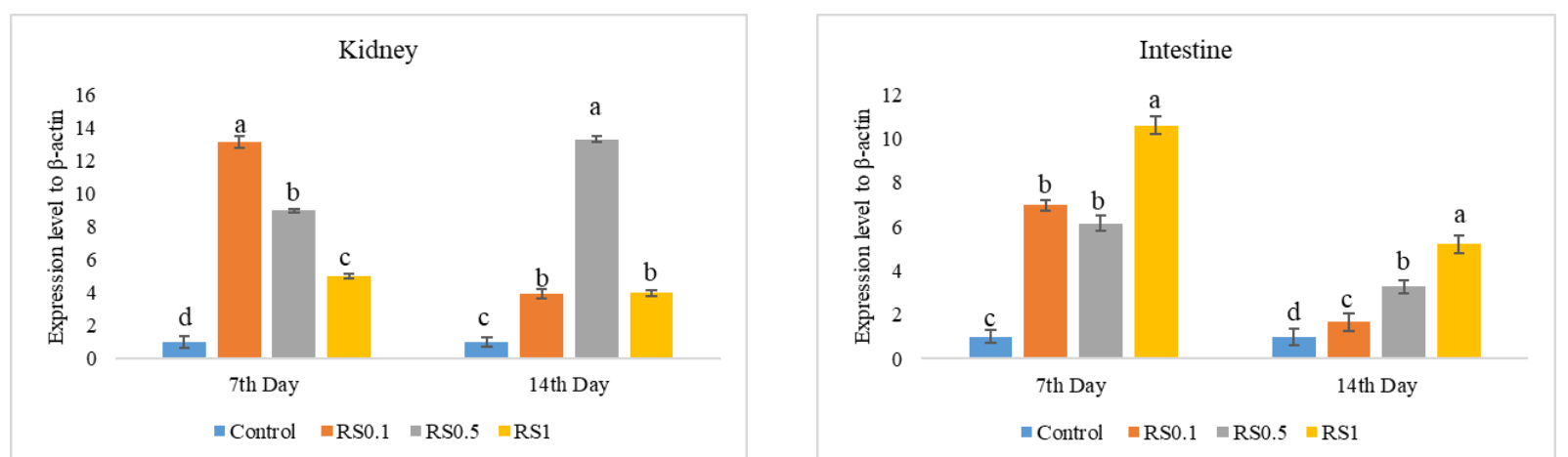

Figure 5. Relative gene expression of IL-8 in the head kidney and intestine cells of rainbow trout treated with different doses of radish seed (Raphanus sativus) by-products aqueous methanolic extract. RS0.1, RS0.5 and RS1, radish seed (Raphanus sativus) byproducts aqueous methanolic extract at 0.10 .5 and $1 \%$ diet, respectively. Values are expressed as mean \pm SE. Different letters above bars indicate significant differences between groups at each sampling day $(P<0.05)$.
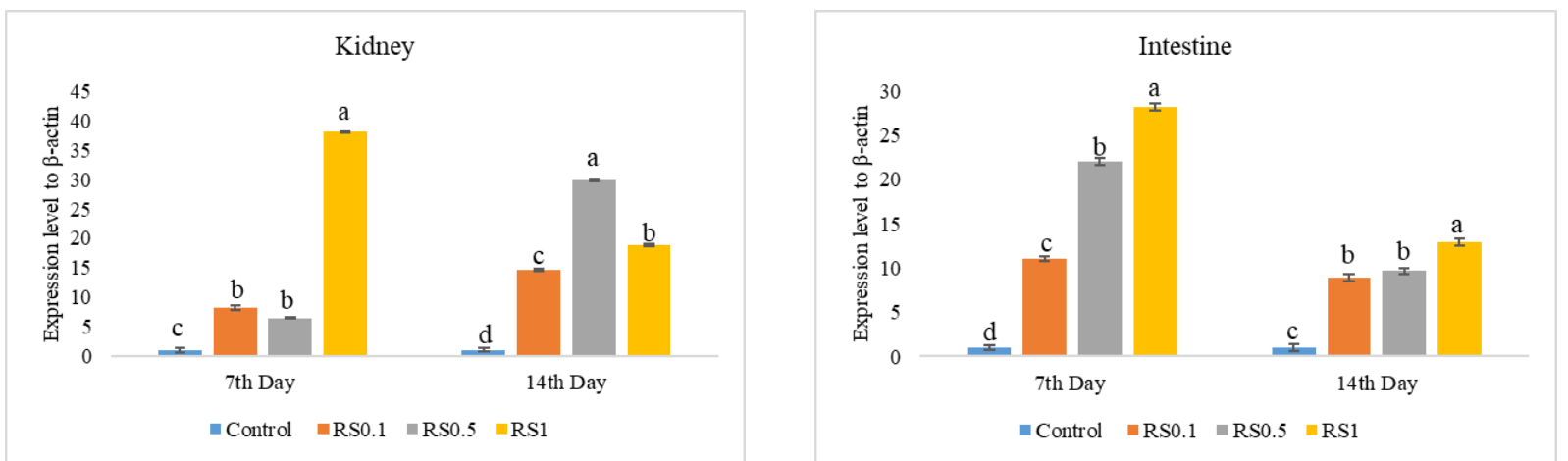

Figure 6. Relative gene expression of IFN-1 in the head kidney and intestine cells of rainbow trout treated with different doses of radish seed (Raphanus sativus) by-products aqueous methanolic extract. RS0.1, RS0.5 and RS1, radish seed (Raphanus sativus) byproducts aqueous methanolic extract at 0.10 .5 and $1 \%$ diet, respectively. Values are expressed as mean \pm SE. Different letters above bars indicate significant differences between groups at each sampling day $(P<0.05)$. 
in the intestine. RS could decrease or regulate the inflammation in intestine. TNF- $\alpha$ is a pro-inflammatory cytokine and has important role on inflammation, defense against bacteria, cell apoptosis and differentiation (Ware, 2003). TNF is secreted in the kidney mainly. The results showed an elevation in both kidney and intestine of the RS fish groups. Similar to that, an increased TNF- $\alpha$ gene expression was observed in rainbow trout after Mentha longifolia application (Heydari et al., 2020).

To determine growth performance, both SGR and FCR are important variables. It is not important to obtain or elevate any positive growth performance in fish fed with a medicinal herb which is being tested for immunostimulant properties. However, in this type of study, we generally focus on assessing any side effects
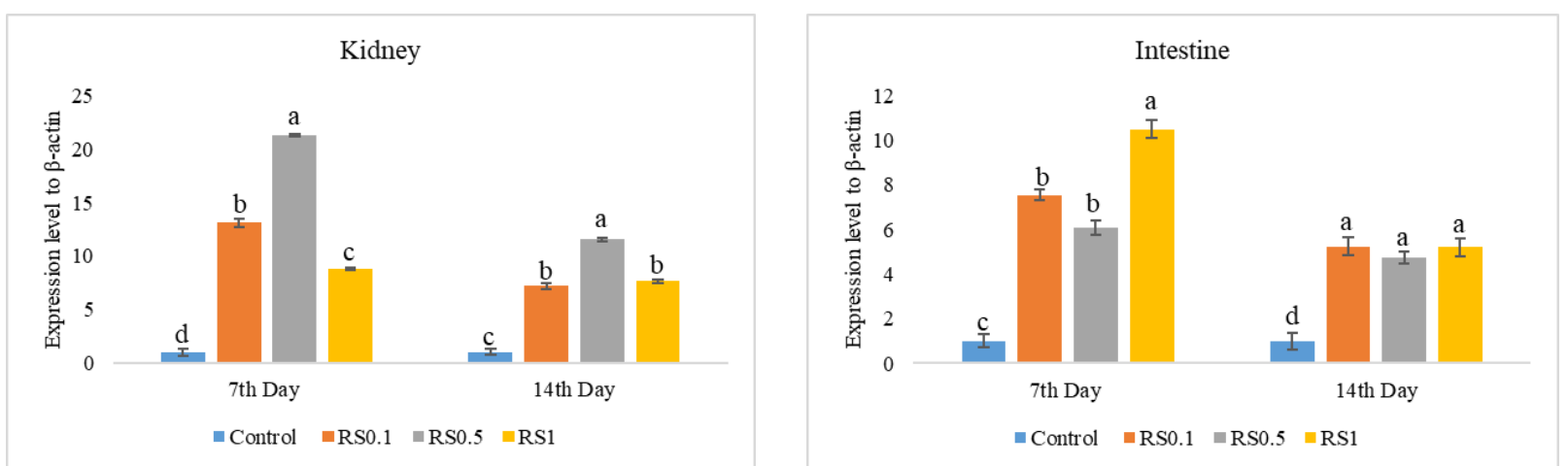

Figure 7. Relative gene expression of IFN-2 in the head kidney and intestine cells of rainbow trout treated with different doses of radish seed (Raphanus sativus) by-products aqueous methanolic extract. RS0.1, RS0.5 and RS1, radish seed (Raphanus sativus) byproducts aqueous methanolic extract at 0.10 .5 and $1 \%$ diet, respectively. Values are expressed as mean \pm SE. Different letters above bars indicate significant differences between groups at each sampling day $(P<0.05)$.
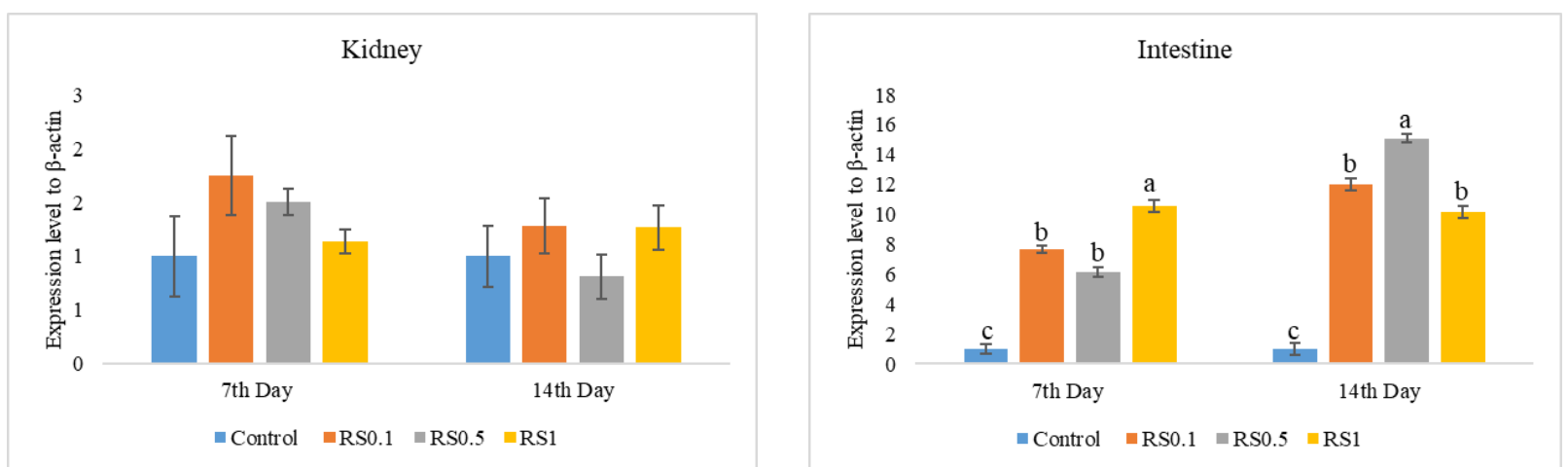

Figure 8. Relative gene expression of TGF- $\beta$ in the head kidney and intestine cells of rainbow trout treated with different doses of radish seed (Raphanus sativus) by-products aqueous methanolic extract. RS0.1, RS0.5 and RS1, radish seed (Raphanus sativus) byproducts aqueous methanolic extract at 0.10 .5 and $1 \%$ diet, respectively. Values are expressed as mean \pm SE. Different letters above bars indicate significant differences between groups at each sampling day $(P<0.05)$.
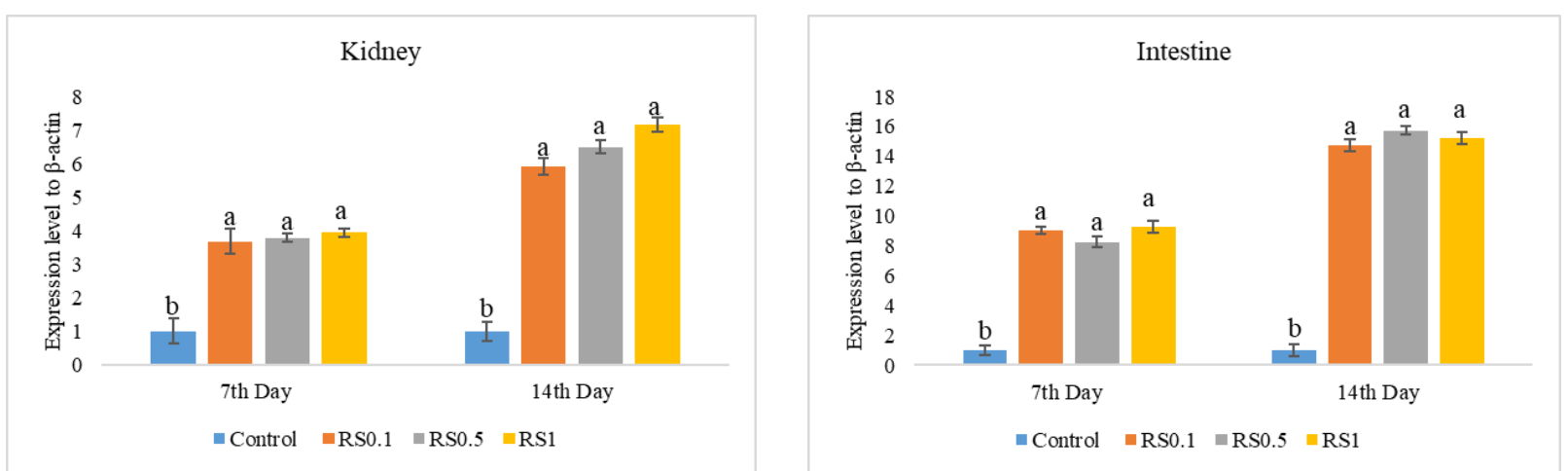

Figure 9. Relative gene expression of TNF- $\alpha$ in the head kidney and intestine cells of rainbow trout treated with different doses of radish seed (Raphanus sativus) by-products aqueous methanolic extract. RS0.1, RS0.5 and RS1, radish seed (Raphanus sativus) byproducts aqueous methanolic extract at 0.10 .5 and $1 \%$ diet, respectively. Values are expressed as mean \pm SE. Different letters above bars indicate significant differences between groups at each sampling day $(P<0.05)$. 


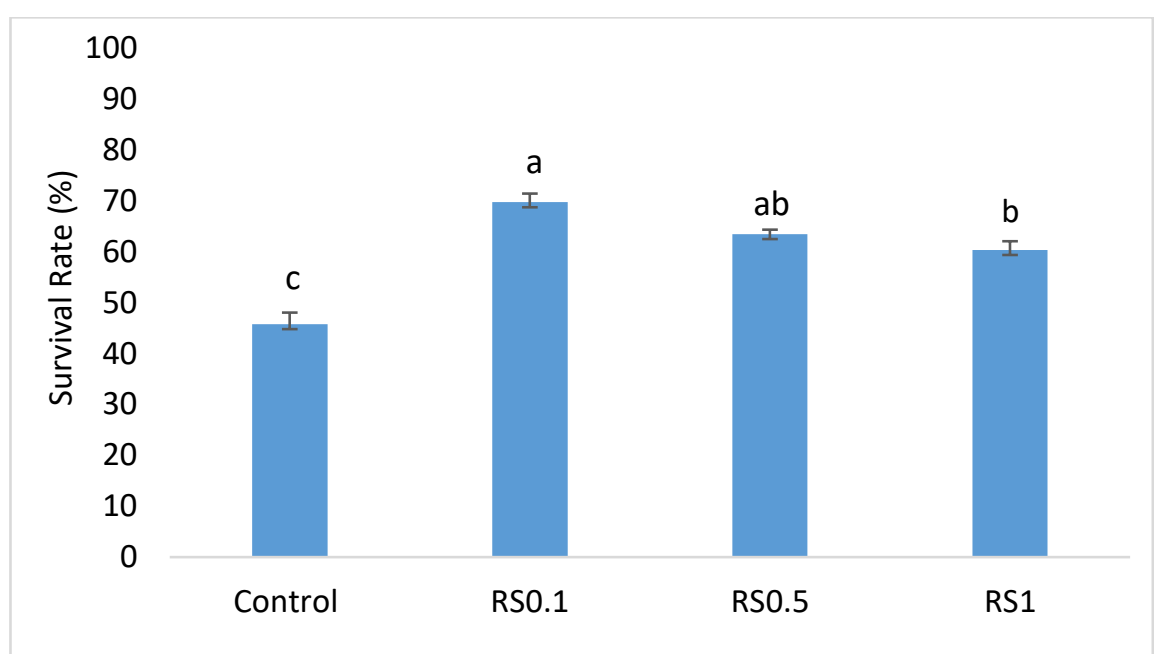

Figure 10. Survival rate (\%) in rainbow trout treated with radish seed (Raphanus sativus) by-products aqueous methanolic extract after challenge with Aeromonas hydrophila. RS0.1, RS0.5 and RS1, radish seed (Raphanus sativus) by-products aqueous methanolic extract at 0.10 .5 and $1 \%$ diet, respectively. Values are expressed as mean \pm SE. Different letters above bars indicate significant differences between groups $(P<0.05)$.

of the herb on growth performance. In the present study, final weight in all treatment groups was enhanced compared to that of control but the highest final weight and SGR were recorded in RS1 fish group. Besides, FCR levels in all treated fish groups did not changed compared to that of the control. Similarly, Malva sylvestris administration in carp (Bilen et al., 2019b), seabream (Bilen et al., 2019c) and rainbow trout (Rashidian et al., 2020) caused a growth promoting effect. On the contrary, in few previous experiments, no growth promotion effect was observed in goldfish fed with nettle (Bilen et al., 2014), and in rainbow trout fed with tetra and laurel (Bilen and Bilen, 2012).

Survival in RS treated fish improved against $A$. hydrophila infection in the present study. Radish contains many components in its extract. When we screened the radish seed extract, an antimicrobial, antifungal and antitumor (Ullah et al., 2015) chemical, benzaldehyde (13.32\%) was obtained in the extract. Triazole is also an important component of the radish extract (30.98\%). Triazole is a well-know antifungal agent (Verweij et al., 2016). However, we speculate that with its antimicrobial effects benzaldehyde probably caused an enhanced survival in treated fish in the study and it was supported by the increased bacterial killing activity in the fish blood. Also, an elevated lysozyme level with its opsonin property could induce high survival rate against $A$. hydrophila.

\section{Conclusion}

Radish seed by-product aqueous methanolic extract was tested as a growth promoter and immunostimulant even with a short span administration. Also, an elevated survival in treated fish against $A$. hydrophila infection is a positive sign. All these results suggest that application radish extract through fish diets for 14 days can improve innate immune responses and growth in rainbow trout.

\section{Ethical Statement}

The present study was performed as per the guidelines and permission according to Directive 2010/63/EU obtained from the local Ethics Committee for Animal Research Studies at the Kastamonu University (2019.27).

\section{Funding Information}

The study was not supported by any other project.

\section{Author Contribution}

\section{All was done by Gökhan Arslan}

\section{Conflict of Interest}

The author declares that they have no known competing financial or non-financial, professional, or personal conflicts that could have appeared to influence the work reported in this paper."

\section{Acknowledgements}

The names, degrees, and affiliations who have contributed substantially to a study but do not fulfill the criteria for authorship can be listed in the Acknowledgments section.

\section{References}

Ahmadifar, E., Dawood, M.A., Moghadam, M.S., Sheikhzadeh, N., Hoseinifar, S.H., Musthafa, M.S., 2019. Modulation of immune parameters and antioxidant defense in zebrafish (Danio rerio) using dietary apple cider vinegar. Aquaculture 513, 734412 https://doi.org/10.1016/j.aquaculture.2019.734412

Alexander, J.B., Ingram, G.A., 1992. Noncellular nonspecific defence mechanisms of fish. Annual Review of Fish 
Diseases 2, 249-279. https://doi.org/10.1016/09598030(92)90066-7

Almabrok, A.A., Amhamed, I.D., Mohamed, G.A., Bilen, S., Altief, T.A.S., 2018. Effect of Tilia tomentosa methanolic extract on growth performance, digestive enzyme activity, immune system and haematological indices of common carp (Cyprinus carpio). Marine Science and Technology Bulletin 7(1), 12-20. https://doi.org/10.33714/masteb.421047

Altunoglu, Y.C., Bilen, S., Ulu, F., Biswas, G., 2017. Immune responses to methanolic extract of black cumin (Nigella sativa) in rainbow trout (Oncorhynchus mykiss). Fish Shellfish Immun 67, 103-109. https://doi.org/10.1016/j.fsi.2017.06.002

Amhamed, I.D., Mohamed, G.A., Almabrok, A.A., Altıef, T.A.S., Bilen, S., 2018. Efficacy of Dietary Chenopodium album Extract on Some Health Parameters, Digestive Enzymes and Growth Performance in Juvenile Cyprinus carpio. Alınteri Zirai Bilimler Dergisi 33(2), 165-176. https://doi.org/10.28955/alinterizbd.412455

Anderson, D., Siwicki, A., 1995. Basic hematology and serology for fish health programs.

Awad, E., Austin, D., Lyndon, A.R., 2013. Effect of black cumin seed oil (Nigella sativa) and nettle extract (Quercetin) on enhancement of immunity in rainbow trout, Oncorhynchus mykiss (Walbaum). Aquaculture 388, 193197. https://doi.org/10.1016/j.aquaculture.2013.01.008

Awad, E., El-Fiqi, A., Austin, D., Lyndon, A., 2020. Possible effect of lesser galangal (Alpinia officinarum) extracts encapsulated into mesoporous silica nanoparticles on the immune status of rainbow trout (Oncorhynchusn). Aquaculture Research 51(9), 3674-3684.

https://doi.org/10.1111/are.14717

Bilen, S., Altief, T.A.S., Özdemir, K.Y., Salem, M.O.A., Terzi, E., Güney, K., 2019a. Effect of lemon balm (Melissa officinalis) extract on growth performance, digestive and antioxidant enzyme activities, and immune responses in rainbow trout (Oncorhynchus mykiss). Fish Physiol Biochem, 1-11. http://doi.org/10.1007/s10695-01900737-z

Bilen, S., Altunoglu, Y.C., Ulu, F., Biswas, G., 2016. Innate immune and growth promoting responses to caper (Capparis spinosa) extract in rainbow trout (Oncorhynchus mykiss). Fish Shellfish Immun 57, 206212. http://doi.org/10.1016/j.fsi.2016.08.040

Bilen, S., Karga, M., Altunoğlu, Y.Ç., Ulu, F., Biswas, G., 2020. Immune Responses and Growth Performance of the Aqueous Methanolic Extract of Malva sylvestris in Oncorhynchus mykiss. Marine Science and Technology Bulletin 9(2), 159-167.

https://doi.org/10.33714/masteb.746951

Bilen, S., Kenanoglu, O.N., Terzi, E., Ozdemir, R.C., Sonmez, A.Y., 2019c. Effects of tetra (Cotinus coggygria) and common mallow (Malva sylvestris) plant extracts on growth performance and immune response in Gilthead Sea bream (Sparus aurata) and European Sea bass (Dicentrarchus labrax). Aquaculture, 734251. https://doi.org/10.1016/j.aquaculture.2019.734251

Bilen, S., Kızak, V., Bilen, A.M., 2013. Floating Fish Farm Unit (3FU). Is it an Appropriate Method for Salmonid Production? Marine Science and Technology Bulletin 2(1), 9-13.

Bilen, S., Soydaș, E., Bilen, A. M. (2014). Effects of methanolic extracts of nettle (Urtica dioica) on non-specific immune response of gold fish (Carassius auratus). Alınteri Zirai Bilimler Dergisi, 27, 24-29.

Capkin, E., Terzi, E., Altinok, I., 2015. Occurrence of antibiotic resistance genes in culturable bacteria isolated from Turkish trout farms and their local aquatic environment. Dis Aquat Organ 114(2), 127-137. http://doi.org/10.3354/dao02852

Chevalier, A., 1996. The Encyclopedia of Medicinal Plants Dorling Kindersley. London, UK.

da Silva, B. C., Mouriño, J. L. P., Vieira, F. N., Jatobá, A., Seiffert, W. Q., Martins, M. L. 2012. Haemorrhagic septicaemia in the hybrid surubim (Pseudoplatystoma corruscansx Pseudoplatystoma fasciatum) caused by Aeromonas hydrophila. Aquaculture Research, 43, 908-916.

Dong, C., 2008. TH 17 cells in development: an updated view of their molecular identity and genetic programming. Nature Reviews Immunology 8(5), 337-348. http://doi.org/10.1038/nri2295

Duke, J.A., Ayensu, E.S., 1985. Medicinal plants of China. Reference Publications.

Dulger, B., Gonuz, A., Bilen, S., Jäger, A., 2005. Antimicrobial studies on three Hypericum species from Turkey. South African Journal of Botany 71(1), 100-103. https://doi.org/10.1016/S0254-6299(15)30156-3

Dulger, B., Hacıoglu, N., Bilen, S., 2009. Antimicrobial activity of Cotinus coggyria from Turkey. Asian Journal of Chemistry 21(5), 4139-4140.

Elbesthi, R.T.A., Özdemir, K.Y., Taştan, Y., Bilen, S., Sönmez, A.Y., 2020. Effects of ribwort plantain (Plantago lanceolata) extract on blood parameters, immune response, antioxidant enzyme activities, and growth performance in rainbow trout (Oncorhynchus mykiss). Fish Physiol Biochem, 1-13. https://doi.org/10.1007/s10695-020-00790-z

Ellis, A.E., 1990. Lysozyme assays. Techniques in fish immunology 1, 101-103.

FAO, 2018. The State of World Fisheries and Aquaculture 2018Meeting the sustainable development goals. FAO Rome, Italy.

Gharaei, A., Shafie, M., Mirdar Harijani, J., Hasanein, P., Arshadi, A., 2020. Immune Responses and Haematological Parameters Changes of Rainbow Trout (Oncorhynchus mykiss) under Effects of Dietary Administration of Sumac (Rhus coriaria L.). Journal of Agricultural Science and Technology 22(1), 173-186.

Haddad, G., Hanington, P.C., Wilson, E.C., Grayfer, L., Belosevic, M., 2008. Molecular and functional characterization of goldfish (Carassius auratus L.) transforming growth factor beta. Developmental \& comparative immunology 32(6), 654-663. http://doi.org/10.1016/j.dci.2007.10.003

Heydari, M., Firouzbakhsh, F., Paknejad, H., 2020. Effects of Mentha longifolia extract on some blood and immune parameters, and disease resistance against yersiniosis in rainbow trout. Aquaculture 515, 734586. https://doi.org/10.1016/j.aquaculture.2019.734586

Jun, J. W., Kim, J. H., Shin, S. P., Han, J. E., Chai, J. Y., Park, S. C. 2013. Protective effects of the Aeromonas phages pAh1$\mathrm{C}$ and pAh6-C against mass mortality of the cyprinid loach (Misgurnus anguillicaudatus) caused by Aeromonas hydrophila. Aquaculture, 416, 289-295.

Karimi, M., Paknejad, H., Hoseinifar, S.H., Shabani, A., Mozanzadeh, M.T., 2020. The effects of dietary raffinose on skin mucus immune parameters and protein profile, serum non-specific immune parameters and immune 
related genes expression in common carp (Cyprinus carpio L.). Aquaculture 520, 734525.

https://doi.org/10.1016/j.aquaculture.2019.734525

Kucukgul, A., Gulsafak, I., 2019. Bio-functions of carvacrolsupplemented feeds on lipopolysaccharide-induced rainbow trout (Oncorhynchus mykiss Walbaum, 1792). Iran J Fish Sci 18(2), 205-214.

http://doi.org/10.22092/ijfs.2018.117382

Lange, S., Guđmundsdottir, B.K., Magnadottir, B., 2001. Humoral immune parameters of cultured Atlantic halibut (Hippoglossus hippoglossus L.). Fish Shellfish Immun 11(6), 523-535. https://doi.org/10.1006/fsim.2000.0333

Magnadóttir, B., 2006. Innate immunity of fish (overview). Fish Shellfish Immun 20(2), 137-151.

http://doi.org/10.1016/j.fsi.2004.09.006

Maldonado-Garcia, M., Angulo, C., Vazquez-Martinez, J., Sanchez, V., Lopez, M.G., Reyes-Becerril, M., 2019. Antioxidant and immunostimulant potentials of Chenopodium ambrosioides L. in Pacific red snapper (Lutjanus peru). Aquaculture 513, 734414. https://doi.org/10.1016/j.aquaculture.2019.734414

Mehrabi, Z., Firouzbakhsh, F., Rahimi-Mianji, G., Paknejad, H., 2019. Immunostimulatory effect of Aloe vera (Aloe barbadensis) on non-specific immune response, immune gene expression, and experimental challenge with Saprolegnia parasitica in rainbow trout (Oncorhynchus mykiss). Aquaculture 503, 330-338.

https://doi.org/10.1016/j.aquaculture.2019.01.025

Mohamed, G.A., Amhamed, I.D., Almabrok, A.A., Barka, A.B.A., Bilen, S., Elbeshti, R.T., 2018. Effect of celery (Apium graveolens) extract on the growth, haematology, immune response and digestive enzyme activity of common carp (Cyprinus carpio). Marine Science and Technology Bulletin 7(2), 51-59. https://doi.org/10.33714/masteb.457721

Ooi, E.L., Verjan, N., Haraguchi, I., Oshima, T., Kondo, H., Hirono, I., Aoki, T., Kiyono, H., Yuki, Y., 2008. Innate immunomodulation with recombinant interferon- $\alpha$ enhances resistance of rainbow trout (Oncorhynchus mykiss) to infectious hematopoietic necrosis virus. Developmental \& Comparative Immunology 32(10), 1211-1220. http://doi.org/10.1016/j.dci.2008.03.010

Ortuno, J., Esteban, M., Mulero, V., Meseguer, J., 1998. Methods for studying the haemolytic, chemoattractant and opsonic activities of seabream (Sparus aurata L.) serum, Methodology in fish diseases research. Fisheries Research Services Aberdeen, pp. 97-100. http://doi.org/10.1016/j.fsi.2005.06.007

Öztürk, R.Ç., Altınok, İ., 2014. Bacterial and viral fish diseases in Turkey. Turk J Fish Aquat Sc 14(1), 275-297. http://doi.org/10.4194/1303-2712-v14_1_30

Qin, Y., Lin, G., Chen, W., Xu, X., Yan, Q. 2016. Flagellar motility is necessary for Aeromonas hydrophila adhesion. Microbial Pathogenesis, 98, 160- 166. https://doi.org/10.1016/j.micpath.2016.07.006

Pearce, J., Harris, J. E., Davies, S. J. 2003. The effect of vitamin $\mathrm{E}$ on the serum complement activity of the rainbow trout, Oncorhynchus mykiss (Walbaum). Aquaculture Nutrition, 9(5), 337-340.

Raida, M.K., Buchmann, K., 2008. Development of adaptive immunity in rainbow trout, Oncorhynchus mykiss (Walbaum) surviving an infection with Yersinia ruckeri. Fish Shellfish Immun 25(5), 533-541.

10.1016/j.fsi.2008.07.008
Ramezanzadeh, S., Kenari, A.A., Esmaeili, M., 2020. Immunohematological parameters of rainbow trout (Oncorhynchus mykiss) fed supplemented diet with different forms of barberry root (Berberis vulgaris). Comparative Clinical Pathology 29(1), 177-187. http://doi.org/10.1007/s00580-019-03032-8

Rani, I., Akhund, S., Abro, H., 2008. Antimicrobial potential of seed extract of Raphanus sativus. Pakistan Journal of Botany 40(4), 1793-1798.

Rashidian, G., Kajbaf, K., Prokić, M.D., Faggio, C., 2020. Extract of common mallow (Malvae sylvestris) enhances growth, immunity, and resistance of rainbow trout (Oncorhynchus mykiss) fingerlings against Yersinia ruckeri infection. Fish Shellfish Immun 96, 254-261. https://doi.org/10.1016/j.fsi.2019.12.018

Safari, R., Hoseinifar, S.H., Nejadmoghadam, S., Jafar, A., 2016. Transciptomic study of mucosal immune, antioxidant and growth related genes and non-specific immune response of common carp (Cyprinus carpio) fed dietary Ferula (Ferula assafoetida). Fish Shellfish Immun 55, 242-248. http://doi.org/10.1016/j.fsi.2016.05.038

Sahoo, P., Kumari, J., Mishra, B., 2005. Non-specific immune responses in juveniles of Indian major carps. Journal of Applied Ichthyology 21(2), 151-155. https://doi.org/10.1111/j.1439-0426.2004.00606.x

Sakai, M., Hikima, J. I., Kono, T. 2020. Fish cytokines: current research and applications. Fisheries Science, 1-9.

Savan, R., Sakai, M. 2006. Genomics of fish cytokines. Comparative Biochemistry and Physiology Part D: Genomics and Proteomics, 1(1), 89-101.

Siwicki, A.K., Anderson, D.P., Rumsey, G.L., 1994. Dietary intake of immunostimulants by rainbow trout affects non-specific immunity and protection against furunculosis. Veterinary Immunology and Immunopathology, 41(1-2), 125-139. http://doi.org/10.1016/0165-2427(94)90062-0

Sonmez, A., Ozdemir, R., Bilen, S., Kadak, A., 2019. Effect of Ginseng Root (Araliaceae sp.) Extracts on Sperm Quality Parameters and Reproductive Performance in Rainbow Trout (Oncorhynchus mykiss). The Israeli Journal of Aquaculture-Bamidgeh, IJA_71.2019.1570.

Sönmez, A., Özdemir, R.C., Bilen, S., 2018. Cyclopamine Induced Expression of Immune-related Genes in Rainbow trout (Oncorhynchus mykiss) Head Kidney Leukocytes. The Israeli Journal of AquacultureBamidgeh, 70:1560, 8 pages.

Srichaiyo, N., Tongsiri, S., Hoseinifar, S.H., Dawood, M.A., Jaturasitha, S., Esteban, M.Á., Ring $\varnothing$, E., Van Doan, H., 2020. The effects gotu kola (Centella asiatica) powder on growth performance, skin mucus, and serum immunity of Nile tilapia (Oreochromis niloticus) fingerlings. Aquaculture Reports 16, 100239. https://doi.org/10.1016/j.aqrep.2019.100239

Tran, H.B., Chen, S.-C., Chaung, H.-C., Cheng, T.-C., 2019. Molecular cloning of IL-6, IL-10, IL-11, IFN- $\gamma$ and modulation of pro-and anti-inflammatory cytokines in cobia (Rachycentron canadum) after Photobacterium damselae subsp. piscicida infection. Comparative Biochemistry and Physiology Part B: Biochemistry and Molecular Biology 230, 10-18. http://doi.org/10.1016/j.cbpb.2019.01.004

Ullah, I., Khan, A.L., Ali, L., Khan, A.R., Waqas, M., Hussain, J., Lee, I.-J., Shin, J.-H., 2015. Benzaldehyde as an insecticidal, antimicrobial, and antioxidant compound produced by Photorhabdus temperata M1021. Journal 
of Microbiology 53(2), 127-133.

Van Doan, H., Hoseinifar, S.H., Sringarm, K., Jaturasitha, S., Yuangsoi, B., Dawood, M.A., Esteban, M.A., Ring $\varnothing$, E., Faggio, C., 2019. Effects of Assam tea extract on growth, skin mucus, serum immunity and disease resistance of Nile tilapia (Oreochromis niloticus) against Streptococcus agalactiae. Fish Shellfish Immun 93, 428-435. https://doi.org/10.1016/j.fsi.2019.07.077

Verweij, P.E., Zhang, J., Debets, A.J., Meis, J.F., van de Veerdonk, F.L., Schoustra, S.E., Zwaan, B.J., Melchers, W.J., 2016. In-host adaptation and acquired triazole resistance in Aspergillus fumigatus: a dilemma for clinical management. The Lancet Infectious Diseases 16(11), e251-e260. https://doi.org/10.1016/S14733099(16)30138-4

Wang, T., Husain, M., Hong, S., Holland, J.W., 2014. Differential expression, modulation and bioactivity of distinct fish IL12 isoforms: Implication towards the evolution of Th1like immune responses. European journal of immunology 44(5), 1541-1551. http://doi.org/10.1002/eji.201344273

Wangkahart, E., Secombes, C.J., Wang, T., 2019. Dissecting the immune pathways stimulated following injection vaccination of rainbow trout (Oncorhynchus mykiss) against enteric redmouth disease (ERM). Fish Shellfish Immun 85, 18-30.

http://doi.org/10.1016/j.fsi.2017.07.056

Ware, C.F., 2003. The TNF superfamily. Cytokine and Growth Factor Reviews 3(14), 181-184. http://doi.org/10.1016/s1359-6101(03)00032-7

Wiens, G.D., Glenney, G.W., LaPatra, S.E., Welch, T.J., 2006. Identification of novel rainbow trout (Onchorynchus mykiss) chemokines, CXCd1 and CXCd2: mRNA expression after Yersinia ruckeri vaccination and challenge. Immunogenetics 58(4), 308-323. http://doi.org/10.1007/s00251-006-0084-7

Zhang, H., Thorgaard, G.H., Ristow, S.S., 2002. Molecular cloning and genomic structure of an interleukin-8 receptor-like gene from homozygous clones of rainbow trout (Oncorhynchus mykiss). Fish Shellfish Immun 13(3), 251-258. http://doi.org/10.1006/fsim.2001.0399

Zhu, W., Zhou, S., Chu, W. 2020. Comparative proteomic analysis of sensitive and multi-drug resistant Aeromonas hydrophila isolated from diseased fish. Microbial Pathogenesis, 139, 103930.

Zou, J., Secombes, C.J., 2016. The function of fish cytokines. Biology 5(2), 23.

https://doi.org/10.3390/biology5020023

Pearce, J., Harris, J. E., Davies, S. J. 2003. The effect of vitamin $\mathrm{E}$ on the serum complement activity of the rainbow trout, Oncorhynchus mykiss (Walbaum). Aquaculture Nutrition, 9(5), 337-340.

Savan, R., Sakai, M. 2006. Genomics of fish cytokines. Comparative Biochemistry and Physiology Part D: Genomics and Proteomics, 1(1), 89-101.

Jun, J. W., Kim, J. H., Shin, S. P., Han, J. E., Chai, J. Y., Park, S. C. 2013. Protective effects of the Aeromonas phages pAh1$\mathrm{C}$ and pAh6-C against mass mortality of the cyprinid loach (Misgurnus anguillicaudatus) caused by Aeromonas hydrophila. Aquaculture, 416, 289-295.

Zhu, W., Zhou, S., Chu, W. 2020. Comparative proteomic analysis of sensitive and multi-drug resistant Aeromonas hydrophila isolated from diseased fish. Microbial Pathogenesis, 139, 103930.

da Silva, B. C., Mouriño, J. L. P., Vieira, F. N., Jatobá, A., Seiffert, W. Q., Martins, M. L. 2012. Haemorrhagic septicaemia in the hybrid surubim (Pseudoplatystoma corruscansx Pseudoplatystoma fasciatum) caused by Aeromonas hydrophila. Aquaculture Research, 43, 908-916.

Qin, Y., Lin, G., Chen, W., Xu, X., Yan, Q. 2016. Flagellar motility is necessary for Aeromonas hydrophila adhesion. Microbial Pathogenesis, 98, 160- 166. https://doi.org/10.1016/j.micpath.2016.07.006

Sakai, M., Hikima, J. I., Kono, T. 2020. Fish cytokines: current research and applications. Fisheries Science, 1-9. 